\title{
Mstislav Dobuzhinsky and ukiyo-e: new visual horizons ${ }^{1}$
}

\section{Svitlana Shiells}

Emailsvitlanavfs@gmail.com

\begin{abstract}
For Western modern artists Japonisme was like a new religion - a stimulus that offered salvation from the conservative grasp of academism and unimaginative realism. Fin de siècle Eastern European artists also gradually developed a strong fascination with Japan and its culture. This paper examines one of the most enthusiastic advocates of Japonisme - a Russian-Lithuanian artist Mstislav Dobuzhinsky. Placing Dobuzhinsky's art in the broader context of Eastern European Japonisme, this paper examines the role of Japanese stimuli in Dobuzhinsky's artistic pursuits. Starting from the early 1900s, Dobuzhinsky's art was visibly recast under the influence of Japanese aesthetics. The paper argues that Japanese aesthetics brought electrifying new ideas into Dobuzhinsky's art and not only played a seminal role in the formation of his style but may have ignited his interest in graphics.
\end{abstract}

KEYWORDS: Mstislav Dobuzhinsky, Japonisme, Mir Iskusstva, ukiyo-e, Hiroshige, Hokusai

Shrouded in mystery, Japan was almost completely inaccessible to the Western world, except to the Dutch, for more than two centuries. ${ }^{2}$ Such extended isolation significantly contributed to the emergence of unprecedented interest in the archipelago. In the mid-1850s, after Commodore Perry's decisive visits to the Land of the Rising Sun, the Japanese opened its ports and signed trade agreements with the United States, Great Britain, France, Russia, etc. Fervent trade brought diverse Japanese artefacts such as kimono, folding screens (byöbu), ink painting and calligraphy on silk and paper, ceramics, etc., to Paris, London, and other major urban centres in Europe and America. Among them ukiyo-e prints proved to be the most popular and influential among artists.

The term ukiyo-e translates as "picture of the floating world" (ukiyo-lit. floating world and $e$-lit. picture). Ukiyo-e is a genre which was developed during the Edo period and focused on subjects such as female beauty, kabuki actors, landscapes, eroticism, etc. Independent from the rigid artistic patronage of the imperial court, the shogunate or religious institutions, ukiyo-e artists expressed themselves freely,

1 I would like to acknowledge the assistance of Olga Kozubska-Andrusiv, Evgeny Steiner, and Clinton Shiells during the work on this paper as well as the help of Irina Jonkers in obtaining sources necessary for my research. Also, I would like to thank the anonymous reviewers and editorial board for their valuable comments. All translations from Russian are mine.

2 The Portuguese discovery of Japan in 1543 led not only to the fruitful trade between the Japanese and Europeans but also to the rapid spread of Christian missionaries' activities especially in the south-western parts of the archipelago. In order to protect Japan from foreign religious influences and consolidate its control over the country, the Tokugawa shogunate introduced its famous isolation policy (Sakoku), which was in effect until the middle of the nineteenth century. 
creating cheap art for the masses. As Christine Guth accentuates, in Edo Japan "aesthetic choices imply competition, and one of the basic facts of artistic survival in urban milieu was finding and keeping an audience." Competition also "contributed to the stylistic eclecticism and pursuit of novelty characteristic" of ukiyo-e prints. ${ }^{3}$ Describing the whimsical world of ukiyo-e, Gian Carlo Calza writes:

It was a shallow world in which the pleasures of life - fashions changing with the predictability of the seasons, celebrity and beauty - had pride of place. A world of wealth and luxury created and destroyed in the space of a dream, and a world of attraction and denial, indulgence and tedium. ${ }^{4}$

However, for Western artists the ukiyo-e world was not just an ephemeral and stylish representation of an exotic and mysterious culture. Appearing against the stormy artistic background that consumed the French capital in the second part of the nineteenth century, ukiyo-e offered western masters the light of hope, igniting their artistic imagination as nothing else before or after. Reflecting on their obsession with Japanese art, Edmond de Goncourt writes: "When I said that Japonisme was in the process of revolutionizing the vision of the European peoples, I meant that Japonisme brought to Europe a new sense of colour, a new decorative system, and, if you like, a poetic imagination in the invention of the objet d'art, which never existed even in the most perfect medieval or Renaissance pieces." 5 Subsequently, artists such as Édouard Manet, Edgar Degas, James Abbott McNeill Whistler, James Tissot, Claude Monet, Pierre-Auguste Renoir, Vincent van Gogh, Felix Vallotton and other members of the Nabis group, Gustav Klimt, Aubrey Beardsley, Thomas Theodor Heiner (the last two were especially popular in fin de siècle Russia) and many other pasionately collected ukiyo-e prints and eagerly experimented with their artistic devices.

At the end of the nineteenth century, following their Western counterparts, Eastern European artists also developed a strong fascination with Japanese art. One of the most enthusiastic advocates of Japonisme on the territory of Russia and Lithuania was the Russian-Lithuanian artist Mstislav Dobuzhinsky (1875-1957). Dobuzhinsky's artistic heritage is rich and diverse, and, as John Bowlt characterizes it, "we cannot fail to be amazed at the breadth and power of Dobuzhinsky's artistic temperament." Aside from numerous graphic works and paintings, he created costume and stage design for theatres in Russia, Lithuania, England, the United States, etc. However, the main emphasis of this essay is neither an analysis of Dobuzhinsky's oeuvre nor an examination of various sources which influenced his art. Rather, this paper focuses exclusively on Dobuzhinsky's engagement with Japonisme, which occurred at

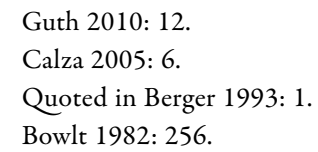


the end of the 1890s and continued throughout his entire artistic career. Russian, Lithuanian, as well as Western scholars developed an interest in Dobuzhinsky's art starting in the early 1900s, although they traditionally view his art through the prism of the St. Petersburg's fin de siècle group Mir Iskusstva (The World of Art) and rarely discuss the role of Japonisme in it. Thus, John Bowlt, ${ }^{7}$ Genady Chugunov, ${ }^{8}$ Janet Kennedy, ${ }^{9}$ Vasily Molodyakov ${ }^{10}$ and others acknowledge the influence of Japanese aesthetics on Dobuzhinsky's art. However, they do not investigate this issue in depth. The Japanese scholar Ueno Rie ${ }^{11}$ briefly discuss the influence of Japanese stimuli on Dobuzhinsky's art. Anna Zavialova, ${ }^{12}$ in a recent short book on Japonisme in the art of the members of Mir Iskusstva, also dedicates a small chapter to Dobuzhinsky, though she treats Japonisme in his art rather as an accidental and therefore unimportant element. This paper argues that Japanese aesthetics brought electrifying new ideas into his art and not only played a seminal role in his formation as an artist and heightened his interest in graphics but was one of the main stimuli in his creative pursuits during his artistic career.

At the end of the nineteenth century, Russian intellectuals developed a strong fascination with Japan and its culture. Eastern European artists and literati were also very familiar with various Western books and periodicals on Japanese culture, among which the famous French journal La Japon Artistique was the most known and, ultimately, sought after. ${ }^{13}$ At the end of the 1890s, a former naval officer, Sergey Kitaev, assembled one of the biggest collections of Japanese art in Europe and enthusiastically advocated for Japanese culture in Russia. ${ }^{14}$ Thus, in 1896, the first exhibition of Japanese art based on Kitaev's collection was displayed at the Academy of Arts in St. Petersburg. In the early 1900s, Kitaev organized two more exhibitions in St. Petersburg and delivered numerous lectures on Japanese culture. Russian artists, mostly the miriskussniki (the members of Mir Iskusstva), such as Igor Grabar, Mstislav Dobuzhinsky, Sergey Shcherbatov, Anna Ostroumova-Lebedeva, Alexander Benois, Ivan Bilibin and many others enthusiastically collected Japanese woodblock prints and consequently experimented with their artistic devices. According to Dobuzhinsky, it was Grabar who introduced him to Japanese art around 1900 in

\footnotetext{
7 Bowlt 1982: 250, 261.

8 Chugunov 1984: 23.

Kennedy 1977: 322.

10 Molodyakov 1996: 94-95.

11 Ueno 2005: 44.

12 Zavyalova 2014: 58-70.

13 La Japon Artistique was published from 1888-1891 (thirty-six issues) by Siegfried Bing in French, German and English. The journal significantly contributed to the popularization of Japanese art.

14 Evgeny Steiner discloses the tragic history of Kitaev and his collection, indicating that a significant part of it was lost due to numerous calamities of the last century and neglect. Now Kitaev's collection - or at least its remains - belong to Pushkin State Museum of Fine Arts in Moscow. See Steiner 2011: 37-63.
} 
Munich. ${ }^{15}$ In his memoir, Dobuzhinsky also acknowledges that he assembled "a big library and many prints," which were accessible for his friends and colleagues. For example, Dobuzhinsky mentions that his Lithuanian friend, artist Mikalojus Konstantinas Čiurlionis, frequently visited him and spent hours in his library, reading and studying his collection. ${ }^{16}$ Besides his own involvement with Japanese culture, Dobuzhinsky gives an account of the collections of other members of Mir Iskusstva, for instance, Benois, who was especially interested in Utamaro and Hokusai. ${ }^{17} \mathrm{He}$ also discusses the Japanese who distributed ukiyo-e prints in Russia. ${ }^{18}$ On account of this, and despite the fact that the wave of Japonisme reached the Russian Empire only at the end of the nineteenth century, it quickly penetrated the hearts and minds of the Russian intelligentsia. As a result, in the early 1900s, Japonisme was already thriving not only in St. Petersburg but in many other urban centres of the Russian Empire. A leading role in its dissemination was played by the miriskussniki, in the first instance by Grabar and Dobuzhinsky.

As a child, Dobuzhinsky lived and studied in Russia, Moldavia and Lithuania. At the end of the 1890s, he travelled to the West in search of the most suitable art school and finished studying with Anton Ažbe in Munich as well as for two brief periods with Simon Hollósy in Hungary. Writing about his study in Munich at the end of the 1890s, Dobuzhinsky underscores: "I am grateful to Grabar for my first acquaintance with Japanese art - in his collection in Munich I saw woodcut prints of Hokusai, Hiroshige and Utamaro."19 In 1900, Dobuzhinsky created one of the first works that reveal his engagement with Japanese stimuli - the painting Munich: Ažbe Studio (Fig. 1). Formally, this work is highly reminiscent of Hiroshige's Kinryüzan Temple in Asakusa (1856), from the series One Hundred Famous Views of Edo (Fig. 2). It is quite possible that Dobuzhinsky encountered this particular print in Grabar's collection and had an opportunity to scrutinize its formal language intensively. Kinryüzan Temple in Asakusa opens the winter section of Hiroshige's series. Its foreground is dominated by two expressive - both in terms of colour and size - forms. On the left, there is the bold vertical form of the gate; on the top there is a huge lantern that occupies a considerable part of the composition. In Munich: Ažbe Studio, Dobuzhinsky utilized a very similar compositional structure: the big cropped vertical segment of the wall on the left as well as a big round metal lamp shade in the centre are direct references to Hiroshige's gate and lantern. It seems that

15 Dobuzhinsky 1987: 192.

16 Ibid.: 304.

17 Ibid.: 208.

18 Ibid.: 192.

19 Ibid. Igor Grabar was one of the most enthusiastic advocates of Japanese art, especially woodblock prints. In 1903, Grabar published the first Eastern European book on the history of nishiki-e - "Japanese colour woodblock prints." It is well known that Grabar accumulated a sizable collection of ukiyo-e and enthusiastically encouraged other Eastern European fellow artists, including Dobuzhinsky, to collect and study them. 


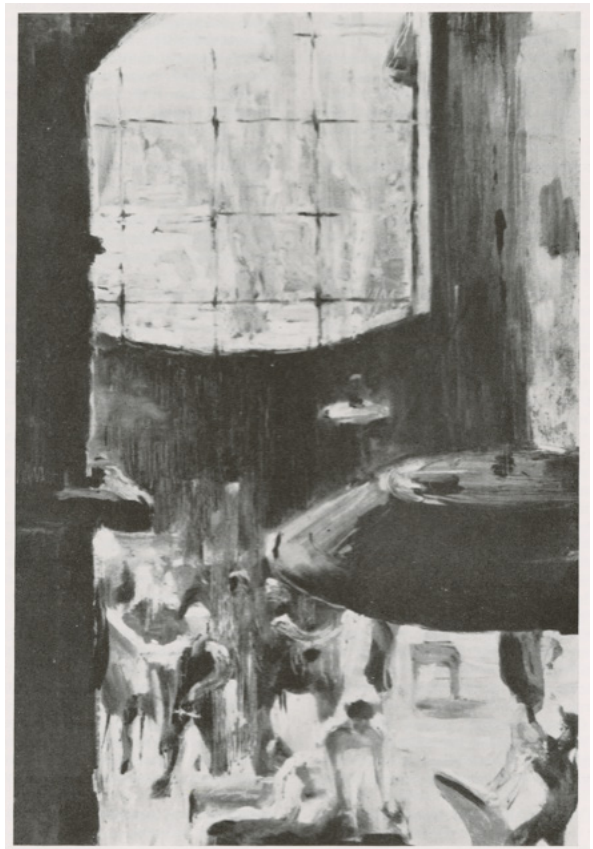

Fig. 1. Mstislav Dobuzhinsky. "Munic: Ažbe Studio", 1900

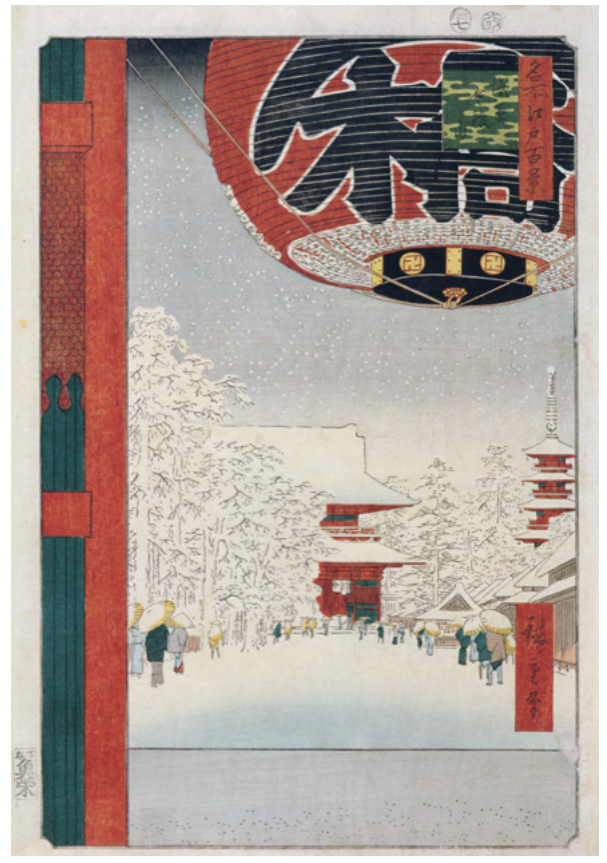

Fig. 2. Utagawa Hiroshige. "Kinryūzan Temple in Asakusa", 1856. From the series "One Hundred Famous Views of Edo"

Hiroshige's formula - with the masterful placement of heavy (structurally and colouristically) blocking forms in the foreground and most of the middle and background occupied by lighter and more delicate forms - deeply resonated with Dobuzhinsky. Following Hiroshige, Dobuzhinsky arranged the heavy forms in the foreground while the big bright window is placed in the background. ${ }^{20} \mathrm{~A}$ similar approach is evident in many of Dobuzhinsky's subsequent works such as $A$ Man with Eyeglasses (1906), Denmark. A Small Theatre (1912), City Types (City Grimaces) (1908), etc. Additionally, in Hiroshige's print, the heavy snowflakes set against the background of a monotonous grey sky create an expressive melodical addition to this 'quiet' composition. This characteristic was also noticed by Dobuzhinsky. A similar treatment of snow, or "Japanese snow"11 as one scholar named it, appeared in a number of his landscapes of St. Petersburg, such as A Small House in St. Petersburg (1905), Night Prince (1909), etc.

The first decades of the twentieth century were the most productive period in Dobuzhinsky's life. In the early 1900s, he settled in St. Petersburg and joined Mir Iskusstva. Dobuzhinsky actively exhibited his works in St. Petersburg and Moscow

20 Chugunov notices this characteristic in Munich: Ažbe Studio, however he does not connect this element to Japanese stimuli. Chugunov 1984: 19.

21 Such an expressive depiction of snow was not exclusively intrinsic to Hiroshige's style. It was utilized by many Japanese artists, especially ukiyo-e masters, starting with Harunobu. 
as well as in Ukraine: in Kiev, Chernigov, Odessa, Kharkov, etc. At the same time, almost every year he habitually spent a couple of months travelling all over Western Europe and also exhibited his works in Munich, Paris, Berlin, etc. Yet, his first personal exhibition was organised in 1907 in Vilnius, Lithuania. Exceptional mobility was one of the main characteristics of Dobuzhinsky's life, which exposed him to different cultures and inevitably considerably enriched his artistic vision. During his frequent travels, the artist inevitably had numerous opportunities not only to see genuine Japanese art, but also to observe its impact on Western European artists, which accordingly enhanced his own interest in Japonisme. Bowlt asserts that among the members of Mir Iskusstva, "Dobuzhinsky was the most receptive and the most flexible in his artistic thinking, and this enabled him to experiment constantly and to assimilate new ideas." 22 During this period, Dobuzhinsky continued to collect and study ukiyo-e. Thus, writing about Japanese prints in his memoir, Dobuzhinsky confesses that in the process of studying ukiyo-e, or in his words "getting deeper and deeper into their world," he "completely fell in love with them." Furthermore, he admits that Hokusai and Hiroshige opened new horizons for him. In particular, he was inspired by Hiroshige's "unexpected composition and decorative qualities of his landscapes." 23

A Man with Eyeglasses (Fig. 3), ${ }^{24}$ one of Dobuzhinsky's best known works, provides more evidence of his interest in Japanese aesthetics. Thus, the frame of the window divides the background into seemingly controlled decorative parts, reminiscent of Far Eastern screen painting. Aside from creating vertical division, the landscape behind the poet is partitioned into register-like strips: greenish fields, greyish fences, multi-coloured buildings and a heavy clouded sky, heightening its decorative quality. Dobuzhinsky acknowledges that he was especially "mesmerised" by the colours and decorative qualities of ukiyo-e. ${ }^{25}$ The poet Konstantin Sunnerberg, lost in his thoughts or dreams in the centre of the composition, seems like an additional large decorative form. On the one hand, this painting betrays Ažbe's training with

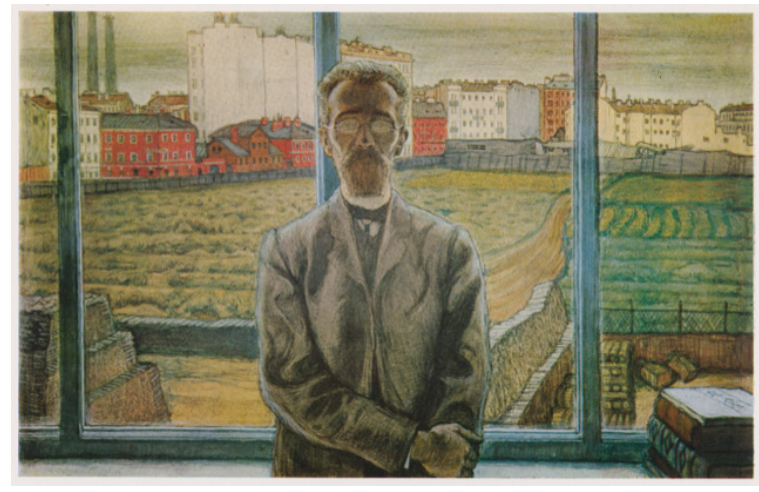

Fig. 3. Mstislav Dobuzhinsky. "A Man with Eyeglasses" ("Portrait of the Poet Constantin Sunnerberg"), 1905-1906

22 Bowlt 1982: 247.

23 Dobuzhinsky also indicates that besides Hiroshige and Hokusai he had in his collections prints of Kuniyoshi, Kunisada, Toyokuni, Eisen and others. Dobuzhinsky 1987: 192.

24 This work is also known under the titles Man with Spectacles or The Portrait of Konstantin Sunnerberg.

25 Dobuzhinsky 1987: 192. 
simplification and unity of forms. On the other hand, it is reminiscent of Hokusai's and Hiroshige's prints of famous places in which people are usually insignificant parts of a landscape.

Examining Dobuzhinsky's art, it is evident that he indeed "was at heart a graphic artist." 26 While Dobuzhinsky's Munich: Ažbe Studio is a painting completed abroad during his study, A Man with Eyeglasses is a graphic work (pencil, gouache and water-colour). In this respect it is important to point out one nuance in Dobuzhinsky's oeuvre around the 1900s. It is well known that Dobuzhinsky went abroad to find the best school to study oil painting at the end of the 1890s, being highly interested in this medium, and finished studying with two teachers in order to fully master the technique. Reflecting on Dobuzhinsky's training in Munich, Grabar highlights that his friend "came to study oil painting seriously." ${ }^{27}$ However, after Dobuzhinsky's return to St. Petersburg, as many scholars notice, the young artist immediately "began to work with Vasilii Mate, a printmaker who headed a studio at the Academy of Fine Arts." 28 Why did Dobuzhinsky suddenly nearly lose interest in oil painting and become fully absorbed in graphics? What was the reason for such a shift? It appears that these important questions have thus far escaped scholarly attention. In retrospect, taking into account Dobuzhinsky's obsession with Japanese prints, it is quite possible that his fascination with ukiyo-e inspired such a change.

In St. Petersburg, Dobuzhinsky produced mostly graphic works: numerous illustrations, vignettes and headpieces for books and art magazines as well as cityscapes, providing him numerous avenues for experimenting with Japanese artistic devices. Dobuzhinsky's 1907 drawing Devil (Fig. 4) quickly generated intense, ongoing interest and much speculation about its meaning as well as the sources of its inspiration, among critics and even the public. ${ }^{29}$ According to one of Dobuzhinsky's letters - which was composed but never sent to an addressee who had apparently inquired about the meaning of this particular grotesque picture - the artist explains that he depicted "the world prison" occupied by people in uniform, moving in a closed circle. ${ }^{30}$ Janet Kennedy points out that Dobuzhinsky's representation of the prison and the circle of people are "based on the print by Gustav Doré Newgate, The Exercise Yard." ${ }^{31}$ However in Devil, the monotonous heavy

\footnotetext{
26 Bowlt 1982: 247.

27 Grabar 2001: 137.

28 Rosenfeld 1999: 89.

29 In 1906, the successor to the journal World of Art, the Symbolist art-literary journal Zolotoe runo (The Golden Fleece) (1906-1909), published in Moscow by Nikolai Riabushinsky, announced a competition for the best work on the theme "Devil." According to Chugunov, Dobuzhinsky was one of several members of the commission in charge of the competition. Although by the end of the year thirty-one works of art had been submitted, the commission was not satisfied with the outcome. As a result, the members of the commission submitted their own work to illustrate what was expected from its participants. See Chugunov 1984: 52-53.

30 Ibid.: 53.

31 Kennedy 1977: 316. Prior to Dobuzhinsky, Doré's print inspired Vincent van Gogh, who created his own very close version of it - Prisoners Exercising (1890).
} 
motion of the group is carefully controlled by a giant spider, which in Bowlt's words is the "most striking description of the Symbolists' taedium vitae." 32 The appearance of a spider-like creature carried the discussion further, since a spider possesses a wide range of meanings. Eugenia Amditis underscores that "divided between Orient and Occident and poised on the cusp between the dying old world and the new twentieth century, the [Russian] Symbolists used the image of the spider to convey simultaneously their ambivalence about their world, their fears for its destruction, and their hopes for its future." The scholar rightly points out that like many Silver Age Russian artists Dobuzhinsky "took inspiration not only from literature and other works of art, but also from different national traditions, East and West," mentioning Japanese art. However, she does follow this path further. Instead, she asserts that Dobuzhinsky depicted "the metaphysical Maya

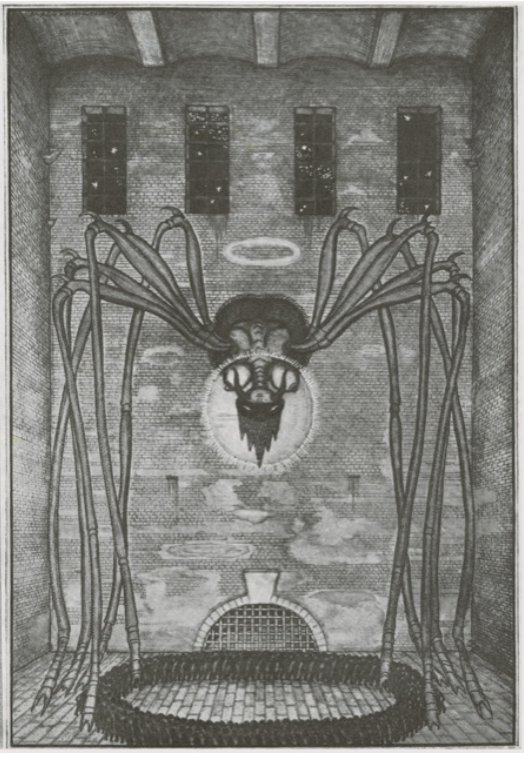

Fig. 4. Mstislav Dobuzhinsky. "Devil", 1907. Illustration for the Magazine Zolotoe Runo, 1907, No. 1 spider that imprisons humanity in illusory matter - in the prison-house of flesh." ${ }^{33} \mathrm{At}$ the same time, Bowlt suggests that when viewed upside down, the spider resembles the feminine forms. ${ }^{34}$ Thus, the scholars add incisive and diverse ideas with a view to deciphering the complexity of Dobuzhinsky's image. However, one source of his inspiration was never brought into the scholarly discussion: Hokusai's Manga.

In 1902, Dobuzhinsky writes that "a small and joyful Japanese person, Hasegawa, appeared in St. Petersburg; he spoke little Russian, but visited a lot of artists here and brought superb Japanese woodblock prints. Everybody was enthusiastically buying them, especially since the prices were not high... I myself - even I could not spend much - bought several woodblock prints and a book of Hokusai's Manga." ${ }^{35}$ It is clear that Dobuzhinsky not only leafed through Hokusai's innumerable visual observations and unusual fantasies collected in his Manga, but diligently studied them. Besides people occupied by everyday as well as the most unorthodox activities, Manga is populated by different samples of flora and fauna, snakes, dragons and other real and imaginary beasts. Among them Hokusai, for instance, frequently depicted 'blood-thirsty'

32 Bowlt 1982: 265.

33 Amditis 2009: 219, 227, 229. Amditis carries this idea much further and argues that "although Dobuzhinsky does not explicitly mention Indian art as an influence upon his work, when the image is inverted, an Indian Goddess appears, complete with numerous topoi from Hindu iconography." Ibid.: 230. It is also known that in 1903 Dobuzhinsky himself wrote a poem Utro (Morning), in which he uses the image of spider.

34 Bowlt 1982: 266.

35 Dobuzhinsky 1987: 192. 


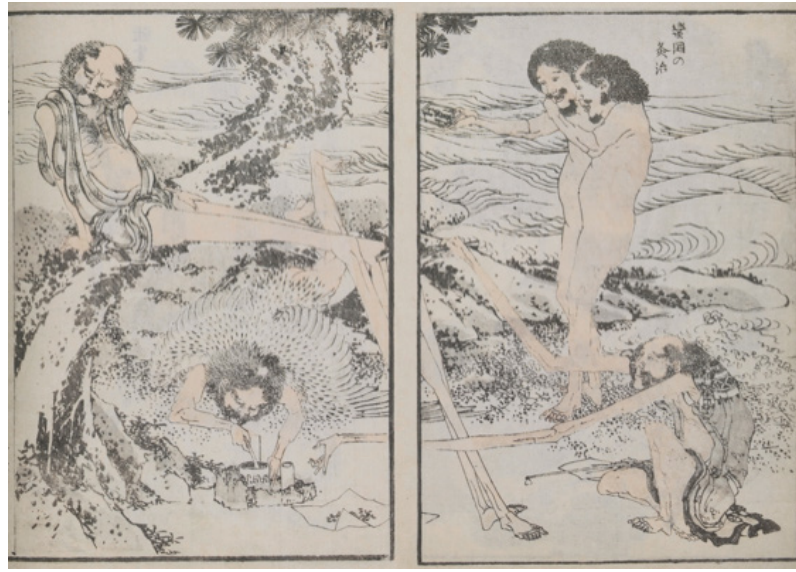

Fig. 5. Katsushika Hokusai. Illustration from "Manga"

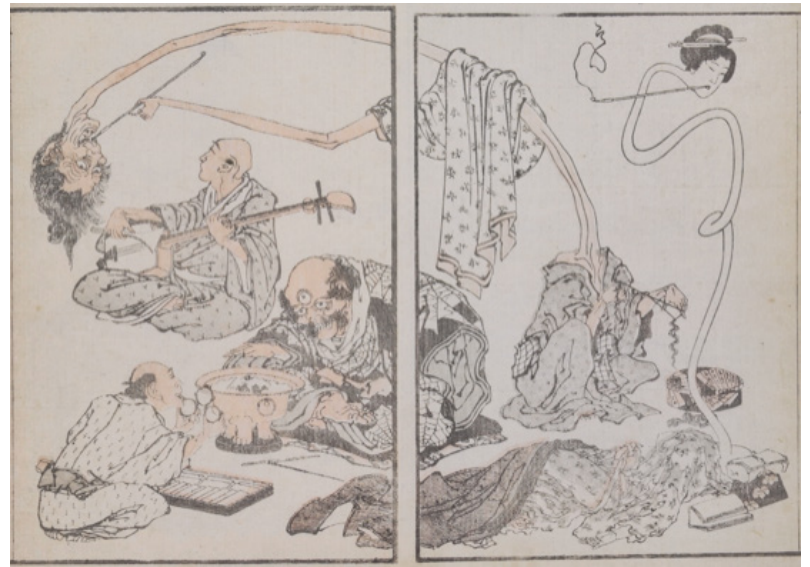

Fig. 6. Katsushika Hokusai. Illustration from "Manga"

octopuses with strong arms, which firmly kept humans in their fatal hugs. ${ }^{36}$ In volume XII, Hokusai introduced a massive spider web and a victim caught in it. However, the victim is not an insect but a human. In volume I, there is a small drawing of a torso of a bald man with big expressive eyes and a huge web behind him. In this case, it seems that the man is not caught by a spider but could be a spider himself. Moreover, besides beasts, Hokusai drew mysterious 'humans' with extensive (a few times longer than an entire body) legs, hands or necks (Figs. 5, 6). Developing Hokusai's fantasies further, Dobuzhinsky created a fierce and powerful image of a spider with exaggerated limbs. The spider, 'the head of the prison' or authority, as Dobuzhinsky himself suggests in the unsent letter, possess total control of the hopeless group. ${ }^{37}$ The tall and dark prison room perhaps symbolises the autocratic grip of the Russian Empire which firmly controlled its narod (people). Thus, it appears that Hokusai's rich imagination inspired Dobuzhinsky to create his own variant of a devil as a massive spider and humans as victims of its whims.

Many scholars have noticed that the theme of the modern city, first of all St. Petersburg, became Dobuzhinsky's favourite subject, which he vividly captured, attaining a particular expressiveness in his black and white prints and drawings. Alla Rosenfelf underscores that "using the whiteness of the page to the maximum, Dobuzhinsky evoked a sense of spatiality which is strongly reminiscent of Japanese art." ${ }^{38}$ Grabar points out the unique characteristic of Dobuzhinsky's 'portraits' of St. Petersburg, indicating that

36 Hokusai utilized images of an octopus not only in Manga but also in some of his erotic prints (shunga) as, for instance, in The Dream of the Fisherman's Wife (1814).

37 Chugunov 1984: 53.

38 Rosenfeld 1999: 89. 
the artist usually depicted the capital not as grand and overwhelming but more intimate and remote, with its gloomy deserted streets and buildings, founding specific poetry in such unusual places. ${ }^{39}$ Tonal gradation and contrast, sudden displacement of perspective, heightened sense of ornamentation (iron grilles, filigree, etc.), architectonic character of composition, noticeable absence of human faces (as, for instance, a faceless crowd in Holiday (1906)) - these and many other principles common to many of Dobuzhinsky's cityscapes from this period are also part of the ukiyo-e language.

In the early 1900s, not only Dobuzhinsky but many other members of Mir Iskusstva developed a strong interest in cityscapes and often depicted St. Petersburg, Moscow or other Russian cities. Chugunov views this as a reflection of their interest in history and suggests that it resulted in the appearance of numerous "historic compositions", as he calls them. On the one hand, the art historian rightly notices that the miriskussniki avoided the depiction of specific historical events on a regular basis. Chugunov observes that Dobuzhinsky, reproducing the spirit of the epoch, took "random cadre from the past life"; even more importantly - from ordinary life without any significant historic connotations. As an example, he cites Dobuzhinsky's work The Provinces in the 1830s (1907-09) (Fig. 7), the depiction of a town Staraja Russa (Старая Pусca) near Novgorod. ${ }^{40}$ On the other hand, Chugunov failed to place such 'historic compositions' within the context of the fin de siecle artistic milieu that permeated St. Petersburg, in particular, to connect this phenomena to Dobuzhinsky's interest in ukiyo-e.

In this case, a comparison of The Provinces in the 1830s with Hiroshige's art provides many unexpected insights. In 1800 , Edo (modern day Tokyo), the seat of the shogun, became the most populated city in the world. At the same time, Japanese became less restricted in their travelling. Everyone who visited Edo was searching for an affordable and meaningful souvenir. Ukiyo-e, especially those which depicted the famous places (meisho) of Edo, Kyoto as well as other important sites and routes - were one of

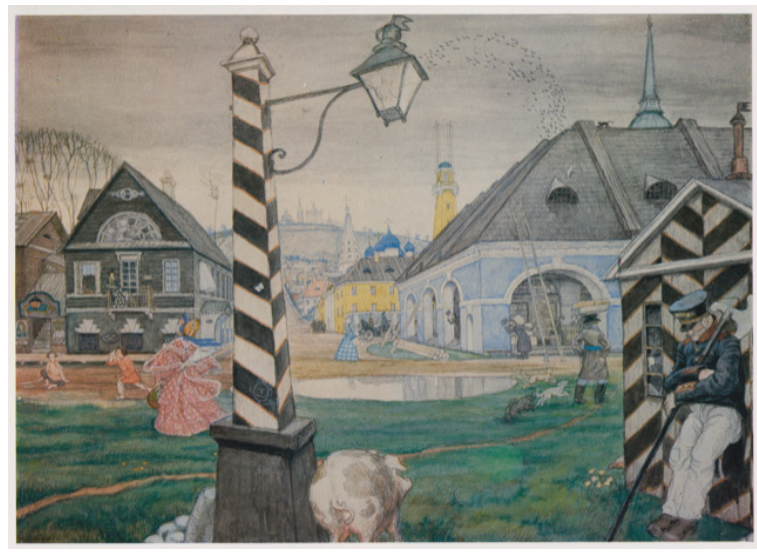
the most affordable ${ }^{41}$ and practical

Fig. 7. Mstislav Dobuzhinsky. "The Provinces in the 1830s", 1907-1909

39 Grabar 2001: 152-153.

40 Chugunov 1984: 54-56. Chugunov's view dominated the Soviet and Russian scholarly domain for many decades since his monograph was for a long time the only study of Dobuzhinsky's oeuvre. Neither Chugunov nor anyone else attempted to track the possible sources of influence on this and many other similar 'historic compositions' and contextualize this phenomenon.

41 In nineteenth century Japan, ukiyo-e prints were very inexpensive. One print cost as little as a bowl of soup - ramen. 
souvenirs since it was easy to carry. As a result, at the beginning of the nineteenth century, Japanese artists - first of all Hokusai and Hiroshige - received numerous commissions to create series of meisho prints (especially picturesque views of Edo). Such ukiyo-e were extremely popular in Japan. For instance, some of Hiroshige's prints were reprinted up to 15,000 times. ${ }^{42}$ Accordingly, meisho prints - notably from Hiroshige's series One Hundred Famous Views of Edo - became widely available in the West and found their way into the collections of many avant-garde artists, ${ }^{43}$ including Dobuzhinsky and other miriskussniki.

In many prints from One Hundred Famous Views of Edo, Hiroshige repeatedly places overwhelmingly large and expressive - frequently blocking or suddenly protruding - details of the composition in the foreground, while the historically important buildings or even Mount Fuji are barely identifiable in the back. ${ }^{44}$ For instance, in the print Dyers' Quarter, Kanda (1857) (Fig. 8), the hanging pieces of drying cloth occupy more than half the space of the print and accordingly significantly block and distract from the beautiful view behind. In the background, between the vertical forms of cloth, the discernible shogun's castle and watch-tower are nesting in front of the familiar shape of Mount Fuji. Similar to Hiroshige, in The Provinces in the 1830s, Dobuzhinsky placed ordinary objects, such as a wide street, a body of water on the square, a post, or unassuming grey buildings, in the foreground, while the historical buildings and churches are located far in the background, on the hill. In addition, in the foreground, the black and white chequered geometric pattern of two structures (police post and guard booth) corresponds directly to Hiroshige's design of the hanging cloth. Moreover, Dobuzhinsky went even further and shocked his viewers with the unexpected placement of a pig, which unassumingly turned its bottom to the viewers in the very centre of the foreground. In the prints Ushimachi, Takanawa (1857) and Bikuni Bridge in Snow (1858), Hiroshige depicted dogs from the back, which some might mistake for pigs. However, in the famous print Naitō Shinjuku, Yotsuya (1857) (Fig. 9), Hiroshige occupied the biggest part the composition with a depiction of a horse's rear. As Henry D. Smith II puts it, Hiroshige went as far as depicting a notorious down-to-earth cityscape from a vantage point "two feet above the ground, between the butt of a horse and its scattered droppings." 45 On the streets and squares of Russian provincial towns it was not surprising to see pigs, chickens or other domesticated animals. However, no one in Russia - even the Peredvizhniki (the Wanderers) - allowed themselves to place an animal's rear in the centre of the foreground. Inspired by Japanese examples, Dobuzhinsky as well as many other western artists challenged old standards. As the artist himself explains,

\footnotetext{
42 Trede and Bichler 2007: 7.

43 It is well known that Hiroshige's prints entered the collections of many Western European artists such as Whistler, Monet, van Gogh and many others.

44 This compositional approach was actively applied by Hokusai, while Hiroshige developed it even further.

45 Smith II and Poster 1986. Plate 86.
} 


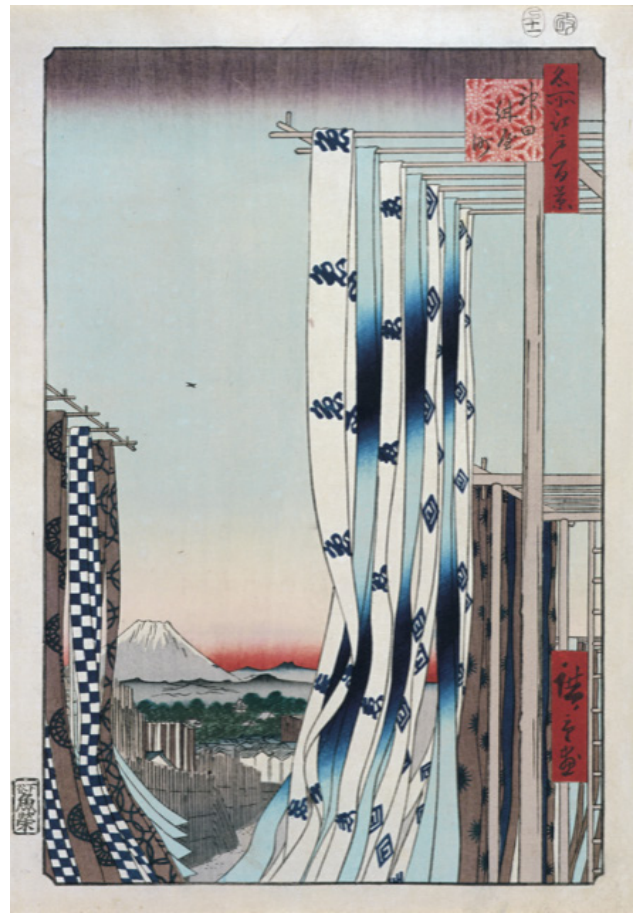

Fig. 8. Utagawa Hiroshige. “Dyers' Quarter, Kanda”, 1857. From the series "One Hundred Famous Views of Edo"

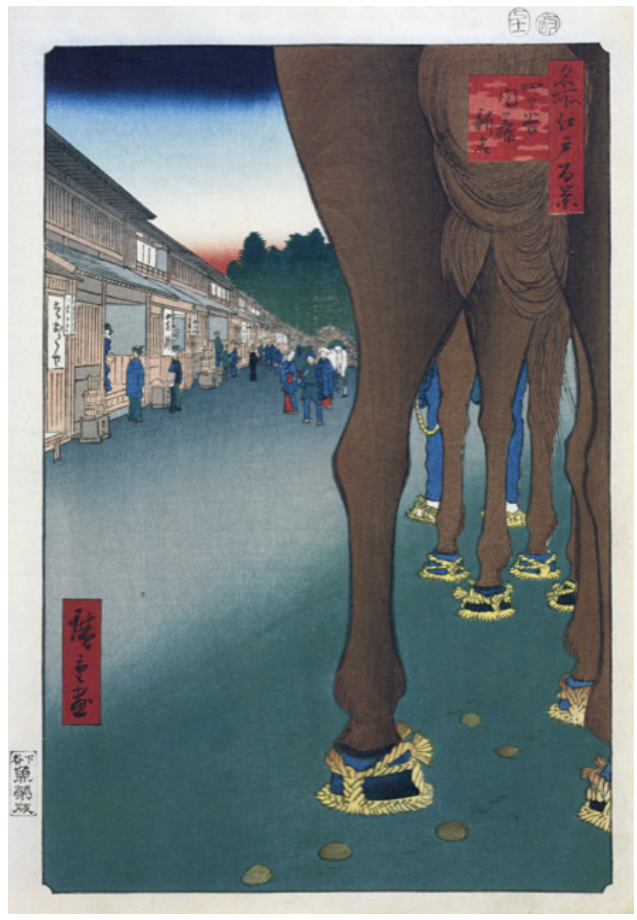

Fig. 9. Utagawa Hiroshige. "Naitō Shinjuku, Yotsuya”, 1857. From the series "One Hundred Famous Views of Edo"

"I liked to choose such point of view that makes a composition sharp, not banal, and in this situation, I always saw Hiroshige in front of me." ${ }^{36}$ Thus, the examination of Dobuzhinsky's The Provinces in the 1830s alongside some Hiroshige's prints from One Hundred Famous Views of Edo reveals not only numerous parallels. It indicates additionally that Dobuzhinsky and his colleagues at Mir Iskusstva were not interested in the creation of 'historical compositions' as had been proposed by Soviet and Russian scholars. ${ }^{47}$ Rather, inspired by the Japanese depictions of famous places, they were developing a similar approach in their cityscapes. In the early 1900s, many members of Mir Iskusstva (for instance, Aleksander Benois) indeed became captivated by the popularisation of the historic and cultural icons on the vast territory of the Russian Empire. Pursuing such objectives, they accordingly adopted the principles of the presentation of famous places used by Japanese artists. This example is a showcase for the importance of Japonisme in understanding fin de siècle Eastern European art.

Starting from 1907, Dobuzhinsky began to work as a stage designer, creating costumes and decor for theatres in St. Petersburg and Moscow, closely collaborating

46 Dobuzhinsky 1987: 190.

47 On rare occasions, Dobuzhinsky and other miriskussniki insert some historic personalities, however, they do not accentuate their presence but rather understate it. For instance, in Dobuzhinsky's Peter the Great in Holland (1910), Peter I and his companion are almost lost among expressive forms of the foreground and powerful sky. 
with Constantin Stanislavski at the Moscow Arts Theatre as well as with Sergei Diaghilev. ${ }^{48}$ While elements of Japonisme were also present in Dobuzhinsky's stage projects, an examination of Dobuzhinsky's stage design is beyond the scope of this paper. After the Revolution of 1917, unimaginable changes shook the Russian capital and the whole Empire. Dobuzhinsky recalls:

I stayed over all revolutionary years in St. Petersburg. With the Revolution of 1917 St. Petersburg died. Before my eyes, I saw that the city was gracefully dying, and I tried within my capacity to record its frightful, uninhabited and wounded guise. That was the epilogue of its former life - it was turning into a different city - Leningrad, already with altogether different people and a different life. ${ }^{49}$

In 1924, the artist forever left Russia and moved to Lithuania, the birthplace of his father, settling in Kaunas, where he stayed until the mid-1930s. In Kaunas, Dobuzhinsky worked at a state theatre and created stage design for almost forty plays, besides running a private art school. Living in Lith-

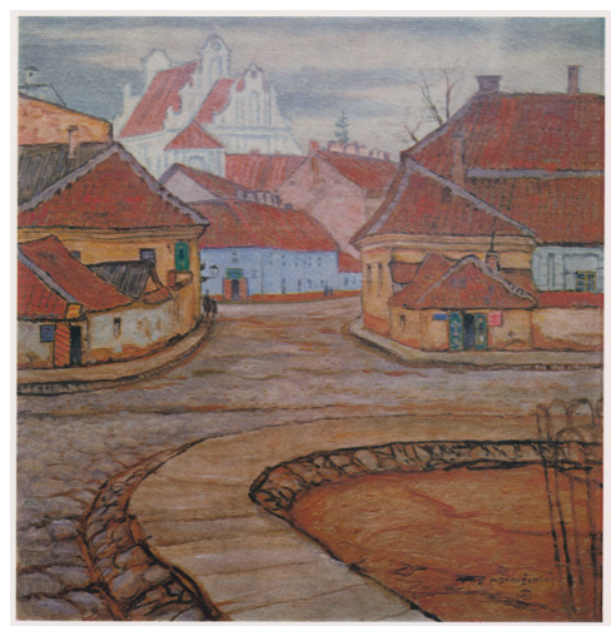

Fig. 10. Mstislav Dobuzhinsky. "Vilno (Vilnius) Cobblestone Street", 1907 uania, Dobuzhinsky produced a series of cityscapes of Vilnius (Vilno), Kaunas and other Baltic towns. The Baltic landscapes indicate that Japanese aesthetics not only significantly shaped Dobuzhinsky's style but also changed his vision. The majority of Dobuzhinsky's Baltic landscapes, for instance, Vilno (Vilnius). Cobblestone Street (1907) (Fig. 10), are united by a slow melodic rhythm of forms, 'quiet' flat colours as well as visible asymmetry, diagonal compositions, expressive decorativeness, cropping, introduction of $S$-curves and other artistic devices which the artist observed in ukiyo-e.

In 1935, Dobuzhinsky emigrated to England and, in 1939, to the United States. After WW II he returned to Europe but, nevertheless, still kept travelling to New York and working on different projects. Discussing Dobuzhinsky's oeuvre, Bowlt writes:

It is this breadth of artistic vision - one which enabled Dobuzhinsky to produce non-figurative compositions in the 1940s side by side with figurative works - which distinguishes Dobuzhinsky from Benois, Bilibin, Ostroumova-Lebedeva, Somov,

48 Janet Kennedy notices that one of the surviving scenes The Bridge for the play Nikolai Stavrogin, at Stanislavsky's Moscow Art Theater in the fall of 1913, adapted for the stage from Dostoevsky's Demons (Besy), resembles Hiroshige's art. See Kennedy 1977: 322.

49 Dobuzhinsky 1987: 23. 
etc. The latter, for all their elegance and finesse, retained a uniformity of technique and theme, so that a Benois or a Somov, whether early or late, pure or applied, is instantly recognizable. Not so with Dobuzhinsky, whose artistic physiognomy changed continually - so making him a very complex subject of investigation for the art historian. ${ }^{50}$

However, during Dobuzhinsky's entire artistic career one thing withstood all kinds of changes - his enduring interest in Japanese aesthetics. As the artist attests in his memoir, since the early 1900s he periodically returned to the Japanese prints and "until this day their art is necessary for me." ${ }^{51}$

For many modern artists Japonisme was almost like a new religion - a stimulus that offered salvation from the conservative grasp of academism and unimaginative realism. Dobuzhinsky undoubtedly was one of them. Starting from the early 1900s, Dobuzhinsky's art visibly reverberated under the influence of Japanese aesthetics. Moreover, it is quite possible that even Dobuzhinsky's interest in graphics was influenced by ukiyo-e. Over time, the elements of Japonisme - deeply observed and transformed - became an organic part of Dobuzhinsky's art. Furthermore, while engagement with Japonisme was symptomatic of the majority of the miriskussniki, most of them for various reasons rarely or never discussed its importance so sincerely and extensively as Dobuzhinsky did in his letters and memoirs. Knowing well the history of art, Dobuzhinsky deeply understood the continuity of the artistic tradition and, therefore, openly discussed his Far Eastern stimuli. In this regard, Dobuzhinsky's writing is an invaluable source on Japonisme in fin de siècle Eastern European art. Undoubtedly, the investigation of the role of Japanese stimuli in Dobuzhinsky's art based on the example of just a few of his works cannot illustrate the whole scope of this phenomenon. Nevertheless, it shows that Mstislav Dobuzhinsky was one of the most important and dedicated promoters of Japonisme in Eastern Europe, and throughout his career Japonisme was a seminal element of his artistic expression.

Received 12182017

Accepted 03122018

\section{Bibliography}

1. Amditis, E. K. The Maya spider in Russian symbolism. The Slavic and East European Journal. 2009. 53. 2.

2. Berger, K. Japonisme in Western Painting, from Whistler to Matisse. Cambridge, 1993.

3. Bing, S. Introduction. Artistic Japan. New York, 1888. 1.

4. Bowlt, J. Moscow \& St. Petersburg 1900-1920: Art, Life \& Culture of the Russian Silver Age. New York: The Vendome Press, 2008.

5. Bowlt, J. The Silver Age: Russian Art of the Early Twentieth Century and the "World of Art" Group. Newtonville, Mass.: Oriental Research Partners, 1982.

50 Bowlt 1982: 257.

51 Dobuzhinsky 1987: 192. 
6. Bowlt, J.; Misler, N.; Petrova, E. (eds.). The Russian Avant-garde, Siberia and the East. Milano: Skira, 2014.

7. Calza, G. C. Ukiyo-e. London: Phaidon, 2005.

8. Chugunov, G. Mstislav Valerianovich Dobuzhinsky. Leningrad: Hudozhnik RSFSR, 1984.

9. Davydova, O. Ikonografia Moderna: Obrazy Sadov i Parkov v Tvorchestve Russkogo Simvolisma. Moskva: BuksMart, 2014.

10. Dobuzhinsky, M. Vospominaniya. Moskva: Nauka, 1987.

11. Dorontchenkov, I. (ed.). Russian and Soviet Views on Modern Western Art. Translated by C. Rougle. Berkeley: University of California Press, 2009.

12. Grabar, I. MoiaZhizn: Avtomonografia. Etudy o Khudozhnikah. Moscow: Respublika, 2001.

13. Guth, C. Art of Edo Japan: The Artist and the City 1615-1868. New Haven: Yale University Press, 2010.

14. Kennedy, J. The "Mir Iskusstva" Group and Russian Art, 1898-1912. New York: Garland Publishing, 1977.

15. Molodyakov, V. 'Obraz Yaponii'v Europe i Rossii v pervoy polovine XIX - nachale XX vekov. Moskva: Institut Orientologii, 1996.

16. Nikolaeva, N. Yaponiya-Evropa. Dialog v Iskusstve. Seredina XVI - Nachalo XX Vekov. Moskva: Izobrazitelnoe Iskusstvo, 1996.

17. Nunokawa, Y. Japonisme and Japonaiserie in fin-de-siècle Europe and its influence on art and music. Kürybos erdvès. 2014. 20.

18. Rosenfeld, A. (ed.). Defining Russian Graphic Arts: From Diaghilev to Stalin, 1898-1934. New Brunswick, N. J.: Rutgers University Press, 1999.

19. Smith, H. D.; Poster, A. G. Hiroshige: One Hundred Famous Views of Edo. New York: G. Braziller, 1986.

20. Stevens, R. A. T.; Wada, Y. I. (eds.). The Kimono Inspiration: Art and Art-to-wear in America. San Francisco: Pomegranate Artbooks, 1996.

21. Steiner, E. Hokusai Manga: The Encyclopaedia of Old Japanese Life in Pictures. St. Petersburg: Center for Oriental Studies, 2016.

22. Steiner, E. Kartinki bystrotechnogo mira. Novyj Mir. 2010. 2.

23. Steiner, E. The Kitaev collection in the Pushkin Museum: Historia Calamitatum. Impressions. The Journal of the Japanese Art Society of America. 2011. 32.

24. Petrov, V.; Kamensky, A. The World of Art Movement in Early 20th-Century Russia. Translated by A. Shkarovsky-Raffe. Leningrad: Aurora Art, 1991.

25. Trede, M.; Bichler, L. (eds.). Hiroshige: One Hundred Famous Views of Edo. Köln: Taschen, 2007.

26. Ueno, R. Japonisumu Kara Mita Roshia Bijutsu. Tōkyō: Tōyō Shoten, 2005.

27. Wichmann, S. Japonisme: The Japanese Influence on Western Art since 1858. London, 2001.

28. Zavyalova, A. Mir Iskusstva: Japonisme. Moskva: BuksMart, 2014.

\section{Svitlana Shiells}

\section{Mstislavas Dobužinskis ir ukijo-e: naujieji vizualiniai horizontai}

\section{Santrauka}

Vakarų menininkams modernistams japonizmas buvo kaip nauja religija - akstinas, pasiūlęs išsigelbẻjimą iš konservatyvaus akademinio suvokimo ir kasdieniško realizmo. Rytų Europos fin de siècle menininkai taip pat palaipsniui susižavejjo Japonija ir jos kultūra. Straipsnyje nagrinejjama vieno iš entuziastiškiausių japonizmo šalininkų Rusijos ir Lietuvos menininko Mstislavo Dobužinskio kūryba yra vertinama platesniame Rytų Europos japonizmo kontekste, analizuojama Japonijos ịtaka dailininko meniniams siekiams. Pirmaisiais XX a. metais Dobužinskio kūriniai ịgavo naujas formas ir tam turejjo įtakos Japonijos estetika, ị Dobužinskio dailę įnešusi visiškai naujas idèjas, ne tik suvaidinusi svarbų vaidmenị formuojantis jo naujam stiliui, bet galbūt paskatinusi susidomèti grafikos menu.

RAKTAŽODŽIAI: Mstislavas Dobužinskis, japonizmas, „Meno pasaulio“ draugija (Mir Iskusstva), ukijo-e (ukiyo-e), Hirošigè (Hiroshige), Hokusajus (Hokusai) 